\title{
PENGARUH FINANCIAL LITERACY, LIFE STYLE, LOCUS OF CONTROL DAN DEMOGRAFI TERHADAP PERILAKU KONSUMTIF GENERASI MILENIAL DI KOTA SUBANG
}

\begin{tabular}{|c|c|}
\hline \multicolumn{2}{|c|}{$\begin{array}{c}\text { Dilasari1, Sri Mulyati², Asep Kurniawan }^{3} \\
\text { 1STIE Sutaatmadja, Subang - Indonesia } \\
\text { Dilasari912@gmail.com }\end{array}$} \\
\hline INFO ARTIKEL & ABSTRAK/ABSTRACT \\
\hline $\begin{array}{l}\text { Histori Artikel : } \\
\text { Tgl. Masuk : } 23 \text { Januari } 2021 \\
\text { Tgl. Diterima : 01 Maret } 2021 \\
\text { Tersedia Online : } 31 \text { Maret } 2021 \\
\text { Keywords: } \\
\text { Financial Literacy, Life Style, } \\
\text { Locus Of Control Dan } \\
\text { Demografi ,Perilaku Konsumtif } \\
\text { Generasi Milenial }\end{array}$ & $\begin{array}{l}\text { This study aims to determine the effect of financial Literacy, } \\
\text { Life style, Locus of control and demographics on the } \\
\text { consumption behavior of millennial generation in the city of } \\
\text { Subang. Consumptive behavior is an action that prioritizes } \\
\text { desires rather than needs, therefore consumption activities } \\
\text { are actions taken to meet needs, if consumption is } \\
\text { excessive, a consumptive behavior will occur. This research } \\
\text { was conducted to the millennial generation in the city of } \\
\text { Subang, aged } 20 \text { - } 35 \text { years in } 2020 \text {. The method used in } \\
\text { this study is a quantitative method. The number of samples } \\
\text { in this study were } 200 \text { people, sampling using nonprobability } \\
\text { sampling techniques with a purposive sampling approach. } \\
\text { The data analysis technique used in this study is multiple } \\
\text { linear regression analysis. } \\
\text { The results of this study conclude that simultaneous } \\
\text { financial literacy, life style, locus of control, and } \\
\text { demographics influence the consumptive behavior of } \\
\text { millennials in Subang City, Whereas according to the results } \\
\text { of the hypothesis partially financial literacy variables, life } \\
\text { style, positive and significant influence on consumptive } \\
\text { behavior of millennial generation in Subang, locus of control } \\
\text { variables have a negative and significant effect on } \\
\text { consumptive behavior of millennial generation in Subang, } \\
\text { while demographic variables (gender), and demographic } \\
\text { (income) does not affect the consumption behavior of } \\
\text { millennial generation in the city of Subang. }\end{array}$ \\
\hline
\end{tabular}

\section{PENDAHULUAN}

Di era globalisasi saat ini perkembangan teknologi berkembang dengan luas dan mendorong ekonomi suatu negara. Salah satunya dapat dilihat dari perkembangan industri yang telah mampu menyediakan segala sesuatu yang dibutuhkan oleh masyarakat. Perkembangan zaman yang semakin modern dan teknologi yang berkembang pesat sangat mempengaruhi perilaku konsumsi masyarakat. Pola perilaku konsumsi masyarakat saat ini telah bergeser, dari sekedar pemenuhan kebutuhan primer berkembang menjadi pemenuhan kebutuhan sekunder, tersier bahkan komplementer dan lebih bersikap konsumtif. Pemenuhan kebutuhan yang telah bergeser tersebut sangat penting artinya untuk mengantarkan individu pada kehidupan yang selaras dengan lingkungannya (Rianti Hikmah, 2019). 
Namun tanpa adanya batasan tersebut membuat masyarakat memiliki kebutuhan yang semakin beraneka ragam, tidak terbatas dan harus dipenuhi dalam kehidupan setiap harinya. Masyarakat melakukan konsumsi untuk memenuhi kebutuhannya, namun konsumsi tersebut akan menjadi masalah jika masyarakat lebih mengutamakan keinginan dari pada kebutuhannya, sehingga mendorong berperilaku konsumtif. Karena perilaku konsumtif adalah sebuah fenomena yang hadir di tengah-tengah masyarakat perkotaan maupun pedesaan.

Perilaku konsumtif adalah suatu perilaku membeli barang tanpa adanya suatu pertimbangan yang kuat dan lebih mengutamakan keinginan dari pada kebutuhan (Fattah, Indriayu dan Sunarto, 2018). Kusumaningtuti S. Soetiono selaku anggota dewan komisioner Otoritas Jasa Keuangan (OJK) mengatakan jika masyarakat Indonesia memiliki uang, mereka akan lebih mengutamakan belanja atau konsumsi dibanding menabung (ekonomi.kompas.com, 2015). Apalagi Di zaman era globalisasi saat ini, teknologi telah memanjakan kita dengan cara memudahkan semua kebutuhan masyarakat sehingga kebutuhan dapat cepat dan mudah dijangkau. Namun tanpa adanya pengendalian diri yang baik, di zaman era globalisasi ini ada dampak positif dan negatif terutama bagi masyarakat indonesia khususnya adalah Generasi milenial.

Generasi milenial adalah generasi yang mempunyai karakteristik komunikasi yang terbuka, pengguna sosial yang fanatik, kehidupannya sangat terpengaruh dengan perkembangan teknologi serta lebih terbuka dengan pandangan politik dan ekonomi(Statistik Gender Tematik: Profil Generasi Milenial Indonesia 2018). Generasi milenial kerap dinilai sebagai generasi yang kreatif dan berani mengambil resiko. internet telah mengambil peran yang sangat siginifikan dalam kehidupan masyarakat Indonesia khususnya generasi milenial yang bisa dilihat dari tingkat konsumsi penggunaan internet $88,4 \%$ yang berasal dari kalangan generasi milenial, karena generasi milenial adalah generasi yang secara cepat mengenal teknologi internet, sehingga mereka bisa dikatakan sebagai generasi internet (lilik purwandi dkk, 2020).

Berdasarkan data indonesia Milenial Report Pada tahun 2019 milenial cukup konsumtif menggunakan uangnya mayoritas pengeluaran milenial sebanyak $51,1 \%$ uang milenial dihabiskan untuk keperluan rutin sedangkan untuk tabungan menunjukan sebanyak $10.7 \%$ dan yang terakhir hanya $2 \%$ minat milenial untuk investasi. Oleh karena itu terlihat bahwa generasi milenial lebih banyak membelanjakan uangnya untuk memenuhi perilaku konsumtifnya dibandingkan menyimpan uangnya untuk ditabung.

Berdasarkan $50 \%$ pembelanja eccomerce merupakan generasi Millenials (berusia antara 25-34 tahun), disusul Generasi-Z (15-24 tahun) sebanyak 31\%, Generasi-X (35-44 tahun) sebanyak 16\%, dan $2 \%$ sisanya merupakan generasi Baby Boomers (usia 45 tahun ke atas) (markeetrs.com.2018). Sehingga Generasi milenial melibatkan teknologi dalam segala aspek kehidupannya mulai dari keperluan transportasi, membeli makanan, jalan-jalan, berbelanja pakaian atau fashion hingga membeli kebutuhan untuk sehari-harinya. (republika.co.id, 2017).

Milenial yang cenderung boros, tidak bisa menabung, lebih suka nongkrong di cofe, beli gadget, beli barang branded dengan harga selangit dan masih banyak lainnya, Karena generasi milenial yang dinilai telah konsumtif, disebabkan oleh kurangnya pengetahuan keuangan dan perencanaan keuangan yang baik dalam kehidupannya, Oleh karena itu perlu sekali dibekali literasi keuangan di kalangan generasi milenial, agar generasi milenial bisa mempunyai perencanaan keuangan dengan baik sehingga bisa meningkatan kesejahteraan untuk dimasa yang akan datang .

literasi keuangan dapat diartikan sebagai suatu rangkaian proses atau program untuk meningkatkan pengetahuan (knowledge), keterampilan (skill), dan keyakinan (confidence) agar mampu mengelola keuangan pribadi 
dengan lebih baik (Nurlatifah, 2014). Survei Nasional Literasi Keuangan (SNLIK) ketiga yang dilakukan Otoritas Jasa Keuangan (OJK) pada tahun 2019 menunjukkan indeks literasi keuangan mencapai $38,03 \%$ dan indeks inklusi keuangan 76,19\%. Angka tersebut meningkat dibanding hasil survei OJK 2016 yaitu indeks literasi keuangan 29,7\% dan indeks inklusi keuangan 67,8\%. Dengan demikian dalam 3 tahun terakhir terdapat peningkatan pemahaman keuangan (literasi) masyarakat sebesar $8,33 \%$, serta peningkatan akses terhadap produk dan layanan jasa keuangan (inklusi keuangan) sebesar 8,39\%. (https://www.ojk.go.id/id/).

Dengan adanya pengetahuan keuangan yang dimiliki seseorang akan membantu indvidu tersebut dalam mengatur perencanaan keuangannya, sehingga individu bisa memaksimalkan waktu, uang dan keuntungan yang didapatkan oleh individu akan semakin besar dan akan meningkatkan taraf kehidupannya atau kehidupannya akan lebih sejahtera. (Margaretha \& Pambudhi ,2015). literasi keuangan merupakan suatu keharusan bagi tiap individu agar terhindar dari masalah keuangan karena individu seringkali dihadapkan pada trade off yaitu situasi dimana seseorang harus mengorbankan salah satu kepentingan demi kepentingan lainnya, sering terjadi saat seseorang hendak membelanjakan uangnya.

gaya hidup (life style) adalah pola hidup seseorang yang ditunjukan dalam aktivitas, minat, dan opininya dalam arti bahwa secara umum gaya hidup seseorang dapat dilihat dari aktivitas rutin yang dia lakukan, apa yang mereka pikirkan terhadap segala hal disekitarnya, seberapa jauh dia peduli dengan hal tersebut dan juga apa yang dia pikirkan tentang dirinya sendiri dan juga dunia luar (Sathish \& Rajamohan, 2012). Gaya hidup merupakan sesuatu yang menunjukan bagaimana orang hidup, bagaimana membelanjakan uang dan bagimana mengalokasikan waktu. Sehingga bisa disimpulkan bahwa gaya hidup seseorang dinyatakan dalam kegiatan, minat dan kebiasaan dalam membelanjakan uang dan bagaimana mengalokasikan waktu (Mowen \& Minor, 2008).

Gaya hidup bisa dilihat dari minat seseorang dalam membeli suatu produk baik fashion atau barang lain yang dipakai, misalnya orang yang mempunyai gaya hidup yang mewah biasanya orang tersebut selalu berminat membeli barangbarang yang bermerek, populer dan selalu mengikuti perkembangan teknologi, opini bisa dilihat dari cara orang tersebut memilih sebuah barang biasanya orang yang mempunyai gaya hidup yang tinggi lebih memilih memakai barang yang branded agar terlihat percaya diri atau menjadi pusat perhatian, sehingga image nya terlihat berkelas. ketiga adalah gaya hidup bisa dilihat dari aktivitas yang orang lakukan dalam kehidupan sehari-harinya, misalnya contoh aktivitas nya adalah lebih suka jalan jalan atau nongkrong di cofeshop mahal.

Kebiasaan gaya hidup telah mengalami perubahan dalam waktu yang relatif singkat dan cenderung menuju ke arah berlebihan semenjak berkembangnya teknologi smartphone, social media, dan electronic commerse. Tindakan berlebihan dalam mengkonsumsi barang atau layanan jasa demi memenuhi gaya hidup mengakibatkan pemborosan. Individu yang memiliki pengendalian diri yang baik mampu mengontrol pengeluaran untuk gaya hidupnya agar terhindar dari perilaku konsumtif. (Rianti Hikmah, 2019)

Locus of control merupakan cara individu dalam mengontrol perilaku, mengontrol kognisi dan mengontrol keputusan. Robbins dalam Nailatul Hidayah (2018) mendefinisikan locus of control (LoC) sebagai tingkat dimana individu yakin bahwa mereka adalah penentu nasib mereka sendiri. Individu yang memiliki locus of control (LoC) internal adalah orang yang yakin bahwa mereka merupakan pemegang kontrol dirinya atas apapun yang terjadi pada diri mereka. Sedangkan orang yang memiliki locus of control (LoC) eksternal adalah orang yang yakin bahwa apapun yang terjadi pada diri mereka dikontrol oleh kekuatan luar seperti keberuntungan atau kesempatan.(Nailatul hidayah, 2018). 
Faktor lain yang mempengaruhi perilaku konsumtif adalah faktor demografi. Demografi sebagai suatu studi yang mempelajari karakteristik, sikap dan perilaku dan pendapatan. Dari keadaan demografi seseorang dapat ditentukan status keuangan individu. (Dyah Rini Prihastuty, 2018).

Penelitian ini merujuk kepada beberapa penelitian sebelumnya. Dalam penelitian yang dilakukan oleh Zahra Qurotaa'yun, Astrie krisnawati (2019), dan Sri Rahayuningsih (2018), Ramadhani, Rianti Hikmah (2019), Delyana Rahmawany pulungan dan hastina febriaty (2018) menyatakan bahwa literasi keuangan berpengaruh negatif terhadap perilaku konsumtif. Namun menurut penelitian yang dilakukan oleh Risa Astiningrum (2018) , huri liana (2019), anisa nur fauzia, nurdin (2019) literasi keuangan berpengaruh terhadap perilaku konsumtif.

Berdasarkan penelitian yang dilakukan oleh Risa Astiningrum (2018), Rianti Hikmah (2019), Delyana Rahmawany pulungan dan Hastina Febriaty (2018) menyatakan bahwa gaya hidup berpengaruh terhadap perilaku konsumtif. Berdasarkan penelitian yang dilakukan Natasha Shanty Herawati (2015), Penelitian Felicia Claresta Harli et al (2015),menyatakan bahwa demografi (jenis kelamin) tidak berpengaruh terhadap perilaku konsumtif. Sedangkan menurut penelitian yang dilakukan oleh Bashar Ahmad and wasiq (2013) ini demografi (jenis kelamin) berpengaruh terhadap perilaku konsumtif.

Berdasarkan penelitian yang dilakuka oleh Felicia Claresta Harli et al (2015), oleh Huri, Liana (2017), Bashar Ahmad and wasiq (2013) demografi (pendapatan) berpengaruh signifikan terhadap perilaku konsumtif, sedangkan penelitian yang dilakukan oleh Dyah Rini Prihastuty \& Sri Rahayuningsih (2018), menyatakan bahwa pendapatan tidak berpengaruh terhadap perilaku konsumtif.

Berdasarkan penelitian terdahulu banyak hasil penelitian yang tidak konsisten, oleh sebab itu peneliti mencoba untuk mengambil kembali faktor, literasi keuangan, gaya hidup, demografi (jenis kelamin), dan demografi (pendapatan) untuk diteliti kembali pengaruhnya terhadap perilaku konsumtif. Dengan menambahkan variabel locus of control, karena variabel ini masih jarang peneliti yang menelitinya,penelitian ini dilakukan di kota Subang dengan objek generasi milenial.

Berdasarkan latar belakang dan riset gap di atas, maka peneliti tertarik untuk meneliti lebih lanjut mengenai perilaku konsumtif dengan judul penelitan "Pengaruh Financial Literacy, Life Style, Locus Of Control, Dan Demografi Terhadap Perilaku Konsumtif Generasi Milenial Di Kota Subang”.

\section{KERANGKA TEORITIS DAN PENGEMBANGAN HIPOTESIS}

\section{Landasan Teori}

\section{Theory of Planned Behaviour (TPB)}

Theory of planned Behaviour) diperkenalkan oleh icek Azjen tahun 1991 merupakan pengembangan lebih lanjut dari teori perilaku beralasan (Theory of Reasoned Action). TPB merupakan kerangka berpikir konsepual yang bertujuan untuk menjelaskan determinasi perilaku tertentu secara umum. Teori tersebut menjelaskan mengapa seseorang melakukan tindakan tertentu. Theory of planned Behaviour (TPB) Merupakan sebuah teori yang dapat menilai perilaku seseorang berdasarkan faktor dari TPB (Madai hatta dkk, 2017).

Ramdhani (2011) menyatakan bahwa, upaya memahami perilaku individu merupakan topik sentral dalam bidang psikologi. Salah satu teori yang banyak digunakan adalah Theory of Reasoned Action (TRA) yang dikemukan oleh Fishbein dan Ajzen (1975), teori ini dikembangkan lebih lanjut oleh Ajzen (1985) menjadi Theory of planned Behaviour (TPB) yang ditunjuk untuk memprediksi perilaku individu secara lebih spesifik. Teori tindakan yang direncanakan (Theory Of Planned Behaviour) mengemukan bahwa tindakan manusia dibimbing oleh tiga macam faktor yaitu keyakinan (behaviour belief), keyakinan 
tentang harapan normatif dari orang lain, motivasi untuk menuruti dari adanya harapan tersebut (normative belief) dan keyakinan tentang hadirnya faktor yang memfasilitasi atau menghambat perilaku, serta persepsi adanya power pada faktor tersebut (control belief) (machrus dan purwono, 2010).

\section{Generasi Milenial}

Generasi milenial adalah Menurut beberapa pendapat para ahli dari berbagai negara dan profesi Generasi milenial adalah generasi yang lahir pada tahun 1980-2000. (sumber statistik gender tematik: profil generasi milenial indonesia tahun 2018), sedangkan Menurut Hasanuddin Ali dan Lilik Purwandi, (2017) menyebutkan bahwa Generasi milenial adalah mereka yang lahir antara tahun 1981 sampai dengan tahun 2000. Generasi milenial adalah generasi yang mempunyai karakteristik komunikasi yang terbuka, pengguna sosial yang fanatik kehidupannya sangat terpengaruh dengan perkembangan teknologi.

Menurut Desy Arisandy, dkk (2019), Generasi milenial yang disebut generasi $Y$ lahir sekitar 1985 sampai dengan 2000. Generasi milenial pada tahun 2020, yaitu mereka yang berusia 20 - 35 tahun pada tahun 2020. Oleh karena itu penelitian ini meneliti generasi milenial di kota Subang yang berusia 20 tahun sampai 35 tahun pada tahun 2020. Karena usia 20 Sampai 35 tahun merupakan usia yang termasuk pada usia milenial.

Generasi milenial bisa dikatakan sebagai generasi internet (Lilik Purwandi dkk,2020). Ciri-ciri generasi milenial adalah ditandai dengan tingkat pendidikan yang baik dari menurut generasi sebelumnya. Karakteristik lain dari generasi milenial adalah kecanduan internet, percaya diri, dan harga diri tinggi dan lebih terbuka dan bertoleransi terhadap perubahan. Kilber et al (2014).

\section{Financial Literacy (Literasi Keuangan)}

Literasi keuangan merupakan salah satu aspek penting dalam kehidupan dimana individu harus memiliki suatu pengetahuan dan keterampilan untuk mengelola sumber keuangan pribadinya secara efektif demi kesejahteraannya (farah\& Reza 2015). Menurut otoritas jasa keuangan (2016) pengertian literasi keuangan yaitu sebagai suatu rangkaian proses atau kegiatan untuk meningkatkan pengetahuan (knowledge), keterampilan (skill) dan keyakinan (confidence) masyarakat agar mereka mampu mengelola keuangan pribadi dengan lebih baik (Palamba,2018).

Menurut Khrisna, Rofaida dan Sari (2010) bahwa literasi keuangan membantu seseorang agar dapat terhindar dari masalah keuangan. Kehidupan yang baik dan jauh dari masalah keuangan tentunya pasti di inginkan oleh setiap orang. Dalam mencapai kehidupan yang baik dan jauh dari permasalahan keuangan baik dalam setiap pengambilan keputusan. (Dyah Rini Prihastuty dkk, 2019).

\section{4. $\quad$ Life style (Gaya Hidup)}

Gaya hidup adalah pola hidup dari individu di dunia yang di ekspresikan melalui aktivitas, minat, dan opininya dalam arti bahwa secara umum gaya hidup seseorang dapat dilihat dari aktivitas rutin yang dia lakukan, apa yang mereka pikirkan terhadap segala hal disekitarnya dan seberapa jauh dia peduli dengan hal tersebut (Kanserina, 2015). gaya hidup terbentuk dari individu masing-masing gaya hidup terlihat dari aktivitas seseorang yang dilakukan secara rutin dan apa yang dipikirkan dari individu tersebut. Gaya hidup setiap orang menunjukan pada ekspresi akan situasi, pengalaman hidup, nilai-nilai, sikap, harapan (Hariyanto, 2015).

Gaya hidup merupakan atau menunjukan seseorang bagaimana orang hidup, bagaimana orang membelanjakan uang mereka, dan bagaimana orang mengalokasikan waktunyanya. sehingga dapat disimpulkan bahwa gaya hidup merupakan pola seseorang yang dinyatakan dalam kegiatan, minat dan kebiasaan dalam membelanjakan uang dan bagaimana mengalokasikan waktu (Mowen dan Minor, 2008). 


\section{Locus Of Control}

Locus of control (pusat kendali) pertama kali dikemukan oleh julian Rotter, 1966 seorang ahli pembelajaran sosial. Locus of control merupakan sejauh mana orang yakin sebuah peristiwa dalam hidup mereka dipengaruhi atau dikontrol oleh mereka sendiri. Locus of control merupakan faktor psikologis, khususnya pada faktor kepribadian yang dapat mempengaruhi perilaku konsumtif seseorang. Dalam proses pengambilan keputusan seseorang biasanya akan bergantung pada locus of control yang dimilikinya, kepercayaan akan faktor faktor yang menentukan keberhasilan dirinya dimasa depan (Nailatul hidayah dkk, 2018).

Robbins (2008) dalam (nailatul hidayah) mendefinisikan locus of control (LoC) sebagai tingkat dimana individu yakin bahwa mereka adalah penentu nasib mereka sendiri. Menurut Ermawati (2017) adalah sebuah keyakinan seseorang tentang keberadaan kontrol yang dimilikinya terhadap keberhasilan dan kegagalan yang di alaminya serta situasi atau kejadian yang ada didalam kehidupannya.

\section{Demografi}

Demografi adalah suatu ilmu yang mempelajari penduduk di suatu wilayah terutama mengenai jumlah, struktur dan proses perubahannya. Loix, pepermans, Hove (2005) menyatakan bahwa ada beberapa karakteristik demografi yaitu, umur, jenis kelamin, usia, tingkat pendidikan, status perkawinan, pekerjaan, jabatan, dan pendapatan. Robb dan Sharpe (2009) mengatakan demografi sebagai suatu studi yang mempelajari karakteristik, sikap dan perilaku seseorang yang dipengaruhi oleh beberapa faktor seperti jenis kelamin, status pendidikan dan pendapatan.

Dalam penelitian ini faktor demografi yang diambil adalah jenis kelamin dan pendapatan, dimana jenis kelamin merupakan segala hal yang diasosiakan dengan jenis kelamin seseorang, tergolong juga peran, tingkah laku, kecenderungan dan atribut yang lainnya, dimana menjelaskan budaya tertentu (prijatna 2012).

Pendapatan Merupakan nilai maksimun yang dapat dikonsumsi oleh seseorang dalam suatu periode. karena semakin banyak seseorang mempunyai uang maka akan semakin sering juga seseorang tersebut ingin membelanjakan segala sesuatu yang dilihatnya. Hal ini dikarenakan oleh sikap konsumtif yang dimiliki oleh setiap individu.

\section{Kerangka Hipotesis}

Dalam penelitian ini terdiri dari lima variabel independen yaitu Financial literacy, life style, locus of control, dan demografi (jenis kelamin), demografi (pendapatan) serta satu variabel dependen yaitu perilaku konsumtif, berdasarkan landasan teori dan penelitian terdahulu, maka dapat disusun sebuah kerangka hipotesis seperti yang digambarkan dibawah ini :

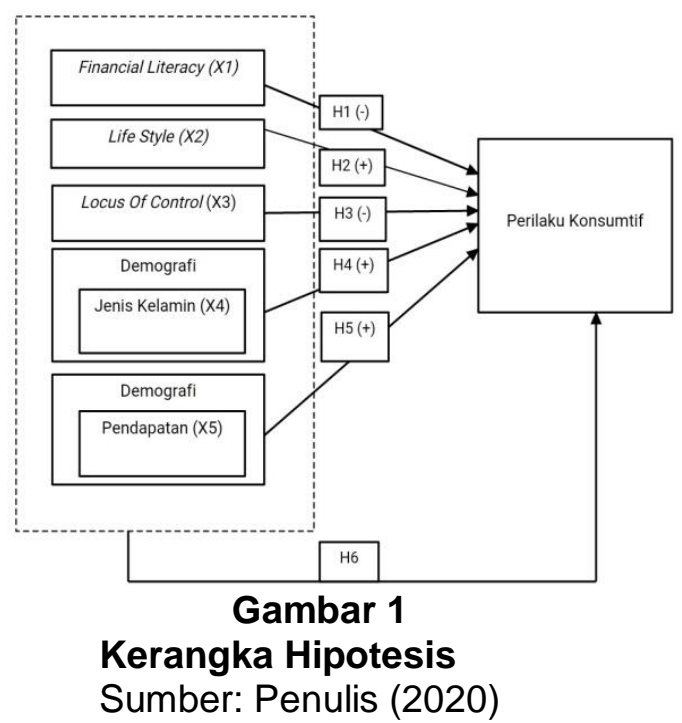

\section{Pengembangan Hipotesis}

\section{Pengaruh Financial Terhadap Perilaku Konsumtif}

Financial literacy merupakan salah satu aspek penting dalam kehidupan dimana orang harus memiliki suatu pengetahuan dan keterampilan untuk mengelola sumber keuangan pribadinya secara efektif demi kesejahteraannya 
(farah\& Reza 2015). Menurut Remund (2010) financial literacy memiliki hubungan dengan kemampuan seseorang dalam mengelola uang.

Hasil penelitian yang dilakukan oleh Zahra Qurotaa'yun \& Asrie Krisnawati (2019) Hasil penelitian ini menunjukan bahwa literasi keuangan berpengaruh negatif terhadap perilaku konsumtif generasi milenial di kota bandung. Dengan tingkat literasi keuangan dan perilaku konsumtif yang termasuk dalam kategori sedang. bahwa apabila literasi keuangan semakin meningkat maka perilaku konsumtif akan semakin menurun, dan begitu pula sebaliknya.

Sedangkan menurut Risa Astiningrum (2018) literasi keuangan berpengaruh terhadap perilaku konsumtif karena menurut Chen dan Volpe (1998.107) dalam Dikria (2016) berpendapat bahwa seseorang yang memiliki pengetahuan yang rendah akan membuat keputusan salah dalam keuangan mereka karena dalam berkonsumsi mereka tidak memperhitungkan prioritas kebutuhan, sedangkan seseorang yang memiliki literasi keuangan yang baik dan selektif dalam berkonsumsi mereka akan memprioritaskan untuk membeli apa yang dibutuhkan dan mengesampingkan apa yang di inginkan. dari beberapa penelitian yang telah disebutkan maka dari itu dapat ditarik hipotesis sebagai berikut.

$\mathrm{H} 1$ : Financial literacy berpengaruh negatif terhadap perilaku konsumtif

\section{Pengaruh Life Style Terhadap Perilaku Kosumtif}

Gaya hidup adalah pola hidup dari seseorang di dunia yang diekspresikan melalui aktivitas, minat, dan opininya dalam arti bahwa secara umum gaya hidup seseorang dapat dilihat dari aktivitas rutin yang dia lakukan, apa yang mereka pikirkan terhadap segala hal disekitarnya dan seberapa jauh dia peduli dengan hal tersebut (Kanserina, 2015). Gaya hidup menunjukan bagaimana orang hidup, bagaimana membelanjakan uang dan bagaimana mengalokasikan waktu. Sehingga bisa disimpulkan bahwa gaya hidup merupakan pola seseorang yang dinyatakan dalam kegiatan, minat dan kebiasaan dalam membelanjakan uang dan bagaimana mengalokasikan waktu (Mowen \& Minor, 2008).

Hasil penelitian yang dilakukan oleh Danang Krisdiantoro, Dr H.susanto M.S Tri Maryati S.E.,M.M (2016) Gaya Hidup berpengaruh positif dan signifikan terhadap Perilaku Konsumtif. Menurut penelitian dari Astiningrum(2018) mengatakan bahwa gaya hidupberpengaruh terhadap perilaku konsumtif, dimana tingkatgaya hidup yang tinggi maka tingkat perilaku konsumtif pun tinggi. Sedangkan penelitian yang dilakukan oleh Delyana Rahmawany pulungan dan hastina febriaty (2018) menujukan bahwa gaya hidup berpengaruh positif dan signifikan terhadap perilaku konsumtif $\mathrm{Hal}$ ini dapat disimpulkan bahwa semakin mewah hedonisme gaya hidup maka akan meningkatkan perilaku konsumtif mereka. dari beberapa penelitian yang telah disebutkan maka dari itu dapat ditarik hipotesis sebagai berikut:

H2 : Life style berpengaruh positif terhadap perilaku konsumtif

\section{Pengaruh Locus Of Control Terhadap Perilaku Konsumtif}

Robbins (2008:138) mendefinisikan locus of control (LoC) sebagai tingkat dimana orang yakin bahwa mereka adalah penentu nasib mereka sendiri. Jadi locus of control dapat diartikan sebagai sebuah penentu nasib mereka sendiri jika mereka mempunyai locus of control yang baik maka mereka akan mempunyai pengelolaan keuangan yang baik. Menurut Ermawati (2017) adalah sebuah keyakinan seseorang tentang keberadaan kontrol yang dimilikinya terhadap keberhasilan dan kegagalan yang di alaminya serta situasi atau kejadian yang ada didalam kehidupannya. Menurut Ida \& Dwinta (2013) locus of control adalah bagaimana seorang individu mengartikan sebab dari suatu peristiwa.

Hasil penelitian yang dilakukan oleh Nailatul Hidayah, prasetyo Ari Bowo 
(2018) menunjukkan locus of control, berpengaruh negatif terhadap perilaku konsumtif. Secara parsial Locus of control berpengaruh negatif dan signifikan terhadap perilaku konsumtif. Hal ini berarti apabila locus of control seseorang meningkat maka perilaku konsumtif seseorang tersebut akan menurun. Sebaliknya, jika locus of control seseorang menurun maka perilaku konsumtif akan meningkat. dari beberapa penelitian yang telah disebutkan maka dari itu dapat ditarik hipotesis sebagai berikut:

H3 : Locus of control berpengaruh negatif erhadap perilaku konsumtif

\section{Pengaruh Demografi (Jenis Kelamin) Terhadap Perilaku Konsumtif}

Demografi adalah suatu ilmu yang mempelajari penduduk di suatu wilayah terutama mengenai jumlah, struktur dan proses perubahannya. Loix, pepermans, Hove (2005) menyatakan bahwa ada beberapa karakteristik demografi yaitu, umur, jenis kelamin, usia, tingkat pendidikan, status perkawinan, pekerjaan, jabatan, dan pendapatan. Jenis kelamin merupakan segala hal yang diasosiakan dengan jenis kelamin seseorang, tergolong juga peran, tingkah laku, kecenderungan dan atribut yang lainnya, dimana menjelaskan budaya tertentu (prijatna, 2012)

Bashar, Ahmad and Wasiq (2013) dalam penelitiannya menjelaskan jenis kelamin berpengaruh positif terhadap perilaku konsumtif. Perempuan memiliki perilaku konsumtif yang lebih tiggi dibandingkan dengan laki-laki, dimana ketika melakukan pembelian perempuan lebih sering didasarkan pada keinginan dan kehidupan sosial,sedangkan laki-laki didasarkan pada kebutuhan. dari beberapa penelitian yang telah disebutkan maka dari itu dapat ditarik hipotesis sebagai berikut:

H4 : Demografi (jenis kelamin) berpengaruh positif terhadap perilaku konsumtif

\section{Pengaruh Demografi (Pendapatan) Terhadap Perilaku Konsumtif}

Pendapatan Merupakan nilai maksimun yang dapat dikonsumsi oleh seseorang dalam suatu periode. Pendapatan ini berasal dari penghasilan yang dimilikinya. semakin tinggi pendapatan individu, maka individu akan cenderung melakukan pembelian lebih tinggi.

Hasil penelitian yang dilakukan oleh penelitian Felicia Claresta Harli (2015) pendapatan berpengaruh positif signifikan terhadap perilaku konsumtif artinya semakin tinggi artinya semakin tinggi pendapatan maka perilaku konsumtif juga akan semakin tinggi. Hasil penelitian yang dilakukan oleh Huri Liana (2019) menyatakan bahwa pendapatan berpengaruh positif artinya semakin tinggi pendapatan yang diperoleh maka akan semakin mempunyai keinginan untuk membeli apa yang diinginkan melebihi apa yang butuhkan. dari beberapa penelitian yang telah disebutkan maka dari itu dapat ditarik hipotesis sebagai berikut:

H5 : Demografi (pendapatan) berpengaruh positif terhadap perilaku konsumtif

\section{Pengaruh Financial Literacy, Life Style, Locus of Control Dan Demografi Terhadap Perilaku Konsumtif \\ Pengaruh financial literacy, life style,} locus of control dan demografi (jenis kelamin), demografi (pendapatan) terhadap perilaku konsumtif dalam penelitian ini didasari oleh teori TPB atau theory of planned behaviour (TPB). Setelah pegujian secara simultan atau secara bersama-sama dengan mengambil hipotesis untuk hubungan financial literacy, life style, locus of control dan demografi pada perilaku konsumtif sehingga ditarik hipotesis sebagai berikut: $\mathrm{H} 6$ : Pengaruh financial literacy, life style, locus of control dan demografi terhadap perilaku konsumtif

\section{METODOLOGI PENELITIAN}


Metodologi Penelitian

Menurut sugiyono

mengungkapkan bahwa : "metode penelitian adalah suatu cara ilmiah untuk mendapatkan data dengan tujuan dan kegunaan tertentu. Metode yang dipilih dan digunakan dalam penelitian ini adalah metode kuantitatif yang diartikan sebagai metode penelitian yang dapat memperoleh datanya dalam bentuk angka (Sugiyono 2016).

Sedangkan teknik pengumpulan data menggunakan metode kuesioner yang dimana Kuesioner yaitu teknik pengumpulan data yang dilakukan dengan cara memberi seperangkat pertanyaan tertulis kepada responden untuk dijawabnya. (Sugiyono, 2016:142). Dalam penelitian ini kuesioner diberikan khusus generasi milenial di kota Subang, berupa angket dan tes pertanyaan yang berhubungan dengan variabel yang dirumuskan berdasarkan indikator yang telah disusun.

\section{Populasi dan Sampel Populasi}

merupakan kawasan yang secara umum terdiri dari subjek atau objek yang mempunyai kualitas dan sifat tertentu yang sudah ditentukan oleh peneliti untuk dipahami atau dipelajari agar bisa ditarik atau didapatkan kesimpulanya (Sugiyono, 2014).

Adapun populasi dalam penelitian ini adalah generasi milenial yang berada di kota Subang

\section{Sampel}

Pengertian sampel menurut Sugiyono (2016) adalah: "bagian dari jumlah dan karakteristik yang dimiliki oleh populasi tersebut."Apabila populasi besar, dan peneliti tidak mungkin mempelajari semua yang ada pada populasi, maka peneliti dapat menggunakan sampel yang diambil dari populasi. Sampel dalam penelitian ini adalah generasi milenial yang berada dikota subang. Penentuan jumlah sampel yang representative menurut Hair et al. (1995 dalam Kiswati 2010) adalah tergantung pada jumlah pertanyaan dikali
5 sampai 10. Jumlah sampel dalam penelitian ini adalah :

Sampel $=$ jumlah pertanyaan $\times 5$

$$
\begin{aligned}
& =33 \times 5 \\
& =165
\end{aligned}
$$

Berdasarkan perhitungan di atas di dapat untuk sampel minimum menggunakan 165 sampel responden yaitu generasi milenal dikota Subang.

\section{Teknik pengambilan sampel}

Teknik yang digunakan dalam penelitian ini adalah menggunakan teknik pengambilan sampel non probablity sampling dengan jenis teknik pengambilan sampelnya ialah purposive sampling. purposive sampling adalah penentuan sampel dengan pertimbangan tertentu( sugiyono, 2014). Kriteria sampel dalam penelitian ini adalah :

1. Generasi milenial yang ber usia 20 35 tahun

2. Generasi milenial yang sudah berpendapatan

3. Generasi milenial yang tinggal Di kota Subang

Teknik sampling digunakan dalam penelitian ini adalah kriteria yang memenuhi untuk dijadikan responden dalam penelitian ini adalah generasi milenial di kab Subang.

Instrumen Penelitian Dan Skala

\section{Pengukuran}

Tabel 1

\begin{tabular}{|c|c|c|}
\hline Variabel & Indikator & $\begin{array}{c}\text { Skala } \\
\text { pengukuran }\end{array}$ \\
\hline $\begin{array}{c}\text { Financial } \\
\text { literacy } \\
\text { (X1) }\end{array}$ & $\begin{array}{l}\text { 1. } \begin{array}{l}\text { Pengetahuan } \\
\text { keuangan } \\
\text { dasar }\end{array} \\
\text { 2. Simpanan dan } \\
\text { pinjaman } \\
\text { 3. Asuransi } \\
\text { 4. investatsi } \\
\text { (Chen dan Volpe } \\
\text { 1998). }\end{array}$ & $\begin{array}{c}\text { Skala Likert } \\
1-5\end{array}$ \\
\hline $\begin{array}{l}\text { Life style } \\
\text { (X2) }\end{array}$ & $\begin{array}{l}\text { 1. } \text { Aktivitas } \\
\text { 2. } \text { Minat } \\
\text { 3. Opini } \\
\text { (Rianti, 2019) }\end{array}$ & $\begin{array}{c}\text { Skala Likert } \\
1-5\end{array}$ \\
\hline
\end{tabular}

Instrument Penelitian 


\begin{tabular}{|c|c|c|}
\hline $\begin{array}{l}\text { Locus of } \\
\text { control } \\
\text { (X3) }\end{array}$ & \begin{tabular}{|ll} 
Locus of control \\
1. & kemampuan \\
& (Ability) \\
2. & minat \\
& (interest) \\
3. & usaha (effort) \\
4. & nasib \\
5. & keberuntunga \\
& $\mathrm{n}$ \\
6. & sosial ekonomi \\
7. & pengaruh dari \\
orang lain \\
(Hidayah dan Ari \\
2018)
\end{tabular} & \\
\hline $\begin{array}{l}\text { Demografi } \\
\text { jenis } \\
\text { kelamin } \\
(X 4)\end{array}$ & $\begin{array}{l}\text { a. Laki-laki } \\
\text { b. Perempuan } \\
\text { (Natasha Shanty } \\
\text { Herawati ,2015) }\end{array}$ & Dummy \\
\hline $\begin{array}{l}\text { Demografi } \\
\text { pendapata } \\
\text { n (X5) }\end{array}$ & \begin{tabular}{llr} 
a. & RP. \\
& 1.500 .000 \\
b. & Rp. 1.500 .000 \\
& - & \multicolumn{2}{c}{ Rp } \\
& 2.500 .000 \\
c. & 2.500 .000 \\
& 3.500 .000 \\
d. & Rp 3.5000 .000 \\
& -4.500 .000 \\
e. & Lebih dari Rp \\
& 4.500 .000 \\
(Siti Fatimah, \\
2019)
\end{tabular} & $\begin{array}{c}\text { Skala Likert } \\
1-5\end{array}$ \\
\hline $\begin{array}{l}\text { Perilaku } \\
\text { Konsumtif } \\
\text { (Y) }\end{array}$ & 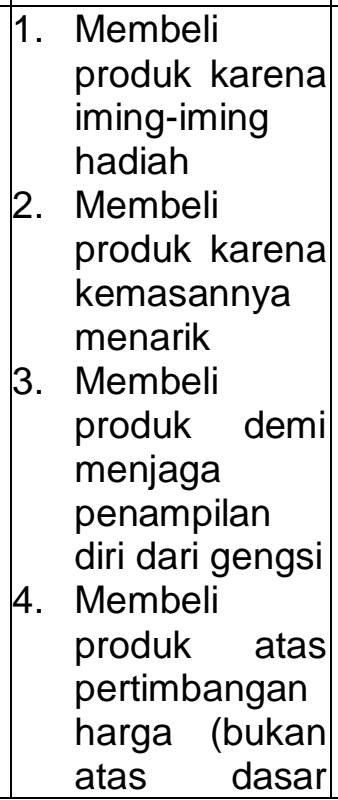 & $\begin{array}{c}\text { Skala Likert } \\
1-5\end{array}$ \\
\hline
\end{tabular}

\begin{tabular}{|c|}
\hline  \\
\hline
\end{tabular}

Sumber: peneliti,2020

\section{Hasil Uji Asumsi Klasik Uji Normalitas}

Uji Normalitas dilakukan dengan tujuan untuk menguji apakah model regresi, variabel pengganggu atau residual mempunyai distribusi normal. Model regresi yang baik adalah yang memiliki distribusi normal atau mendekati normal. Pengujian normalitas pada penelitian menggunakan analisis KolmoggrovSmirnov, grafik, dan scaterplott.

\section{Tabel 2}

Hasil uji normalitas

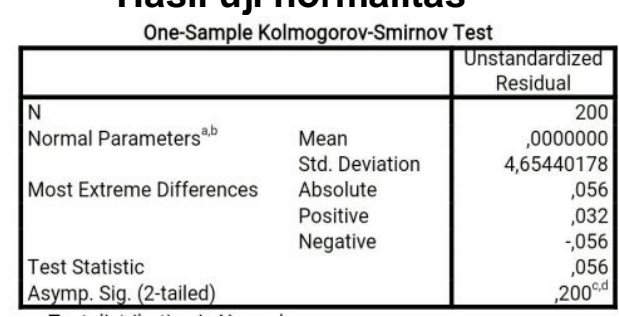

Berdasarkan hasil statistic di atas menunjukan jika dilihat dari hasil statistic bahwa nilai Test Statistic KolmogrovSmirnov adalah 0.05 dan tingkat signifikan 0.200 hal tersebut menunjukan data tersebut berdistribusi normal karena nilai tersebut lebih dari signifikan 0.05 . 


\section{Uji Multikolinieritas}

Uji Multikolinearitas bertujuan untuk menguji apakah model regresi ditemukan adanya korelasi antar variabel bebas (independen). Model regresi yang baik seharusnya tidak terjadi korelasi dantara variabel independen. Nilai cutoff yang umum dipakai untuk menunjukan adanya multikolineriatas adalah nilai tolerance $\leq 0.10$ dan VIF $\geq 10$ (Ghozali, 2013). Berikut ini merupakan output uji multikolonieritas menggunakan bantuan program SPSS v22:

\section{Tabel 3}

Hasil Uji Multikolinearitas

\begin{tabular}{|l|l|c|r|l|}
\hline \multicolumn{2}{|c|}{ Model } & \multicolumn{2}{|c|}{ Collinearity Statistic } & \multicolumn{1}{c|}{ Hasil } \\
\hline \multirow{2}{*}{1} & Tolerance & VIF & \\
\cline { 2 - 4 } (Con(constant) & & & \\
\cline { 2 - 4 } X1 & 0.947 & 1.056 & $\begin{array}{l}\text { Tidak Terjadi } \\
\text { Multikolinearitas }\end{array}$ \\
\cline { 2 - 4 } X2 & 0.843 & 1.187 & $\begin{array}{l}\text { Tidak Terjadi } \\
\text { Multikolinearitas }\end{array}$ \\
\hline X3 & 0.814 & 1.228 & $\begin{array}{l}\text { Tidak Terjadi } \\
\text { Multikolinearitas }\end{array}$ \\
\hline X4 & 0.865 & 1.156 & $\begin{array}{l}\text { Tidak Terjadi } \\
\text { Multikolinearitas }\end{array}$ \\
\hline X5 & 0.871 & 1.148 & $\begin{array}{l}\text { Tidak Terjadi } \\
\text { Multikolinearitas }\end{array}$ \\
\hline
\end{tabular}

Sumber: SPSS versi 22

Hasil pengujian Multikolinearitas pada table di atas menunjukan bahwa variabel Financial Literacy (X1), Life Style (X2),variabel Locus of Control(X3), Demografi (jenis kelamin) (X4), dan Demografi (Pendapatan) (X5) memiliki nilai tolerance $>0.10$ dan memiliki nilai $\mathrm{VIF}<10$. Dengan demkian dapat disimpulkan bahwa variabel bebas yang digunakan dalam penelitian ini tidak terjadi Multikolineritas.

\section{Uji heteroskedastisitas}

Menurut ghozali (2016) Uji Heterokedastisitas bertujuan menguji apakah dalam regresi terjadi ketidaksamaan variance dari residual satu pengamatan ke pengamatan lain. Model regresi yang baik adalah jika variance dari residual satu pengamatan ke pengamatan lain tetap homokedastisitas dan tidak mengalami heteroskedastisitas. Berikut ini merupakan output uji heteroskedastisitas:

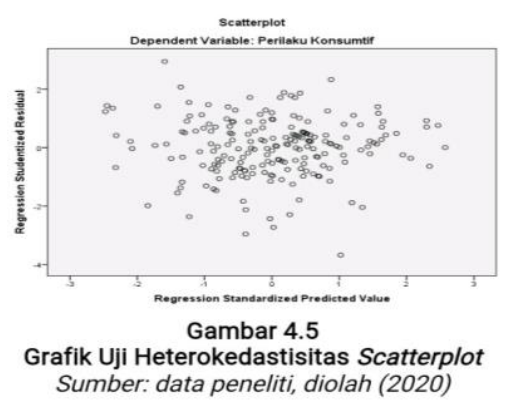

Berdasarkan grafik Scatterplot di atas dapat diketahui bahwa titik- titik menyebar secara acak serta tersebar datas maupun di angka 0 pada sumbu $Y$. Maka dari itu, dapat disimpulkan bahwa tidak terjadi heterokedastisitas pada model regresi, sehingga regresi layak dipakai untuk memprediksi variabel dependen berdasarkan variabel independen.

\section{Analisis Regresi Linier Berganda}

Analisis regresi berganda digunakan untuk mengetahui apakah terdapat pengaruh antara literasi keuanganterhadap pengelolaan keuangan. Persamaan regresinya adalah: $Y=a+\beta 1 X 1+\beta 2 X 2+\beta 3 X 3+\beta 4 X 4+\beta 4 X 5$ $\varepsilon$

Keterangan

Y : Perilaku Konsumtif

A : Konstanta

$\beta \quad$ : Koefisien regresi

$\mathrm{X} 1$ : Financial Literacy

X2 : Life Style

X3 : Locus Of Control

X4 : Demografi Jenis Kelamin

X5 : Demografi pendapatan

e $\quad$ : Tingkat Kesalahan (error of term)

\section{Uji Hipotesis}

Terdapat tiga pengujian hipotesis dalam penelitian ini yaitu koefisien determinan (R2), uji simultan (Uji F), dan uji parsial (Uji t) yang masing-masing dijelaskan yaitu sebagai berikut:

a. Uji Simultan (Uji F)

Dalam Ghozali (2016), Pengujian ini dilakukan untuk mengetahui apakah semua variabel independen secara bersama-sama (simultan) dapat berpengaruh terhadap variabel dependen. 
kriteria pengambilan keputusan dengan menggunakan angka probabilitas siginifikansi dan $\mathrm{F}$ tabel

1. Apabila probabilitas siginifikansi $>0,05$, maka $\mathrm{H} 0$ diterima dan $\mathrm{H} 1$ ditolak yang artinya Financial Literacy, Life Style, Locus of Control dan Demografi secara simultan atau bersama-sama tidak berpengaruh terhadap perilaku konsumtif.

2. Apabila probabilitas siginifikansi $<0,05$, maka $\mathrm{H} 0$ ditolak dan $\mathrm{H} 1$ diterima yang artinya Financial Literacy, Life Style, Locus of Control dan Demografi secara simultan atau bersama-sama mempengaruhi variabel perilaku konsumtif (untuk tingkat signifikansi $=5 \%$ ).

b. Uji Parsial (Uji t)

Menurut Ghozali (2016) "uji statistik $t$ pada dasarnya menunjukan seberapa jauh pengaruh suatu variabel penjelas/independen secara individual dalam menerangkan variabel dependen".

pengambilan kesimpulan adalah dengan membandingkan t hitung dengan $t$ tabel pada taraf signifikan $5 \%$ atau 0,05 . Apabila $\mathrm{t}$ hitung $\geq \mathrm{t}$ tabel maka variabel tersebut berpengaruh secara signifikan, sebaliknya apabila $\mathrm{t}$ hitung $\leq \mathrm{t}$ tabel maka variabel tersebut tidak berpengaruh secara signifikan.

Jika hasil penelitian tidak sesuai dengan arah hipotesis (positif atau negatif) walaupun berada dibawah tingkat signifikan, maka hipotesis ditolak.

\section{c. Uji koefisien determinasi $\left(R^{2}\right)$}

Ghozali (2016) menyatakan

"koefisien determinasi $\left(R^{2}\right)$ pada intinya mengukur seberapa jauh kemapuan model dalam menjelaskan variasi variabel dependen". Nilai koefisien determinasi adalah antara nol dan satu. Nilai $R^{2}$ yang kecil berarti kemampuan variabel-variabel independen menjelaskan variasi variabel dependen amat terbatas. Nilai yang mendekati satu berarti variabel-variabel independen memberikan hampir sama informasi yang dibutuhkan untuk memprediksi variasi variabel dependen. Kelemahan mendasar penggunaan koefisien determinasi adalah bias terhadap jumlah variabel independen, maka $R^{2}$ pasti meningat tidak peduli apakah variabel tersebut berpengaruh secara signifikan terhadap variabel dependen. Oleh karena itu banyak peneliti menganjurkan untuk menggunakan nilai adjusted $\mathrm{R}^{2}$ pada saat mengevaluasi mana model regresi terbaik. Tidak seperti $\mathrm{R}^{2}$, nilai adjusted $\mathrm{R}^{2}$ bisa naik atau turun apabila satu variabel independen ditambah kedalam model (Ghozali, 2016)

Dibawah ini merupakan tabel hasil regresi berganda bertujuan untuk membuktikan ada tidaknya pengaruh dari variabel independen yang terdiri dari variabel financial literacy $\left(\mathrm{X}_{1}\right)$, life Style $\left(\mathrm{X}_{2}\right)$, Locus Of Control $\left(\mathrm{X}_{3}\right)$, demografi (Jenis kelamin) $\left(\mathrm{X}_{4}\right)$, dan Demografi (pendapatan) $\left(X_{5}\right)$, sementara variabel dependen dalam penelitian ini adalah perilaku konsumtif $(Y)$. Berikut merupakan hasil uji rgresi berganda :

\section{Tabel 4.}

Hasil Uji Berganda Regresi

\begin{tabular}{|c|c|c|c|c|c|}
\hline \multirow{2}{*}{ Model } & \multicolumn{2}{|c|}{$\begin{array}{c}\text { Unstandardized } \\
\text { Coefficients }\end{array}$} & $\begin{array}{c}\text { Standardized } \\
\text { Coefficients }\end{array}$ & T & Sig. \\
\cline { 2 - 6 } & B & Std. Error & Beta & & \\
\hline $\begin{array}{c}1 \\
\text { (Constant) }\end{array}$ & 39,033 & 3,917 & & 9,965 &, 000 \\
\hline X1 &, 175 &, 070 &, 133 & 2,495 &, 013 \\
\hline X2 &, 788 &, 305 &, 145 & 2,580 &, 011 \\
\hline X3 &,- 626 &, 060 &,- 601 & $-10,480$ &, 000 \\
\hline X4 &, 050 &, 718 &, 004 &, 069 &, 945 \\
\hline X5 &, 321 &, 253 &, 070 & 1,268 &, 206 \\
\hline
\end{tabular}

Sumber: SPSS versi 22

Berdasarkan tabel di atas, hasil analisis regresi berganda menghasilkan koefisien untuk variabel bebas yaitu $\mathrm{X} 1$. = $0.175 ; \mathrm{X} 2=0.788 ; \mathrm{X} 3=-0.626 ; \mathrm{X} 4=0.050$; dan $X 5=0.321$ dengan konstanta 39.033 Dengan demikian, dapat dihasilkan persamaan regresi berganda sebagai berikut:

$Y=39.033+0.175+0.788-0.626+0.050$ $+0.321 \mathrm{Y}+\mathrm{e}$

Persamaan Regresi berganda di atas memiliki makna sebagai berikut

1. Konstanta (a) sebesar 39.033 artinya apabila Financial literacy, life style, locus off control, demografi (jenis kelamin), dan demografi (pendapatan) 
nilainya 0 . Maka perilaku konsumtif nilainya 39.033

2. Koefisien regresi variabel Financial Literacy (X1), memiliki nilai sebesar 0.175 artinya jika financial literacy mengalami peningkatan satu satuan maka perilaku konsumtif akan mengalami peningkatan sebesar 0.175 ,dengan asumsi variabel lainnya tetap (konstan).

3. Koefisien regresi variabel Life style (X2), Menunjukan nilai sebesar 0.788 , jika variabel Life Style mengalami peningkatan satu satuan maka variabel perilaku konsumtif akan meningkat sebesar 0.788 , dengan asumsi variabel lainnya tetap (konstan).

4. Koefisien Regresi varabel Locus of control (X3), memiliki nilai sebesar 0.626 mengartikan bahwa jika locus of control mengalami kenaikan satu satuan maka variabel perilaku konsumtif akan menurun sebesar 0.626 , dengan asumsi variabel lainnya tetap (konstan).

5. Koefisien regresi variabel demografi (jenis kelamin) (X4), memiliki nilai sebesar 0.050 , artinya jika variabel demografi jenis kelamin mengalami peningkatan satu satuan maka variabel perilaku konsumtif akan meningkat 0.050, dengan asumsi variabel lainnya tetap (konstan).

6. Koefisien regresi variabel Demografi (pendapatan) (X5), memiliki nilai sebesar 0.321 , artinya jika variabel demografi (pendapatan) mengalami peningkatan satu satuan maka variabel perilaku konsumtif akan meningkat 0.321. dengan asumsi variabel lainnya tetap (konstan).

\section{Hasil Uji Hipotesis}

Hipotesis dalam penelitian ini diuji dengan tiga (3) cara yaitu dilihat dari uji simultan (uji F), uji parsial (uji t), dan koefisien determinasi $\left(R^{2}\right)$, berikut adalah penjelasan dari masing-masing pengujian hipotesis:
a. Uji Simultan (Uji F)

Pengujian ini bertujuan untuk mengetahui ada tidaknya pengaruh antara variabel independen $(X)$ dan variabel dependen (Y) secara simultan. Berdasarkan tabel dibawah ini menunjukan bahwa nilai signifikan adalah sebesar 0.000 dimana nilai tersebut kurang dari $0.05 \quad(<0.05)$, hal tersebut menandakan bahwa variabel independen yang terdiri dari variabel financial literacy, life style, locus of control, demografi (jenis kelamin), dan demografi (pendapatan) berpengaruh terhadap perilaku konsumtif. Berikut ini adalah hasil uji simultan dari semua variabel independen terhadap variabel dependen :

\section{Tabel 5}

Hasil Uji Simultan (Uji F)

\begin{tabular}{|l|l|r|r|r|r|c|}
\hline \multicolumn{2}{|c|}{ Model } & $\begin{array}{c}\text { Sum of } \\
\text { Squares }\end{array}$ & Df & $\begin{array}{c}\text { Mean } \\
\text { Square }\end{array}$ & F & Sig. \\
\hline 1 & Regression & 3992,567 & 5 & 798,513 & 35,934 &, $000^{b}$ \\
\hline & Residual & 4311,028 & 194 & 22,222 & & \\
\hline & Total & 8303,595 & 199 & & & \\
\hline
\end{tabular}

Sumber: SPSS versi 22

b. Hasil Uji Parsial (Uji t)

Pengujian ini bertujuan mengetahui pengaruh dari variabel independent $(X)$ terhadap variabel dependen $(Y)$ secara parsial. Dibawah ini adalah hasil uji $t$ dari masing-masing variabel

Tabel 6

Hasil Uji Simultan (Uji t)

\begin{tabular}{|c|c|c|c|c|c|}
\hline \multirow{2}{*}{ Model } & \multicolumn{2}{|c|}{$\begin{array}{c}\text { Unstandardized } \\
\text { Coefficients }\end{array}$} & $\begin{array}{c}\text { Standardized } \\
\text { Coefficients }\end{array}$ & T & Sig. \\
\cline { 2 - 6 } & B & Std. Error & Beta & & \\
\hline $\begin{array}{c}\text { (Constant) } \\
\text { X1 }\end{array}$ & 39,033 & 3,917 & & 9,965 &, 000 \\
\hline X2 &, 775 &, 070 &, 133 & 2,495 &, 013 \\
\hline X3 &,- 626 &, 060 &,- 601 & $-10,480$ &, 000 \\
\hline X4 &, 050 &, 718 &, 004 &, 069 &, 945 \\
\hline X5 &, 321 &, 253 &, 070 & 1,268 &, 206 \\
\hline
\end{tabular}

Sumber: dengan SPSS versi 22

Berdasarkan hasil uji parsial (uji t) pada masing-masing variabel, di dapatkan hasil bahwa tiga dari lima variabel independen berpengaruh pada variabel dependen dengan membandingkan hitung dengan $t$ tabel diketahui $\mathrm{dk}$ (derajat kebebasan) $=n-k=200-6=194$ 
sehingga diperoleh nilai $t$ tabel sebesar 1.65275 dengan tingkat signifikan (0.05). berikut adalah hasil uji t dari setiap variabel

1. Hipotesis pertama $(\mathrm{H} 1)$

Variabel Financial literacy $\left(\mathrm{X}_{1}\right)$ memiliki nilai $t$ hitung sebesar 2.495 lebih besar dari $t$ tabel 1.65275 , serta memiliki nilai signifikan sebesar 0.013 dan dimana nilai tersebut kurang dari $0,05(<0,05)$ dan bertanda positif $(+)$, ini menunjukan bahwa variabel financial literacy berpengaruh terhadap Perilaku konsumtif. Dengan demikian hipotesis pertama $(\mathrm{H} 1)$ diterima.

2. Hipotesis kedua $(\mathrm{H} 2)$

Variabel Life Style $\left(\mathrm{X}_{2}\right)$ memiliki nilai $\mathrm{t}$ hitung sebesar 2.580 lebih besar dari $t$ tabel 1.65275, serta memliki nilai signifikan sebesar 0.011 dan dimana nilai tersebut kurang dari $0,05(<0,05)$ dan bertanda positif $(+)$, ini menunjukan bahwa variabel Life Style berpengaruh terhadap Perilaku konsumtif. Dengan demikian hipotesis kedua $(\mathrm{H} 2)$ diterima.

3. Hipotesis ketiga $\left(\mathrm{H}_{3}\right)$

Variabel Locus Of Control $\left(\mathrm{X}_{3}\right)$ memiliki nilai $t$ hitung sebesar -10.480 lebih kecil dari $t$ tabel 1.65275 , serta memiliki nilai signifikan sebesar 0.000 dan dimana nilai tersebut kurang dari $0,05(<0,05)$ dan bertanda negatif $(-)$, ini menunjukan bahwa variabel Locus of control berpengaruh terhadap Perilaku konsumtif. Dengan demikian hipotesis ketiga $(\mathrm{H} 3)$ diterima.

4. Hipotesis keempat (X4)

Variabel demografi (jenis kelamin) $\left(\mathrm{X}_{4}\right)$ memiliki nilai $t_{\text {hitung }}$ sebesar 0.069 lebih kecil dari $t$ tabel 1.65275 , serta memiliki nilai signifikan sebesar 0.945 dimana nilai tersebut lebih dari $0,05(>0,05)$, ini menunjukan bahwa variabel demografi (jenis kelamin) tidak berpengaruh terhadap Perilaku konsumtif. Dengan demikian hipotesis keempat (H4) ditolak karena variabel demografi (jenis kelamin tidak berpengaruh terhadap perilaku konsumtif

5. Hipotesis kelima $(\mathrm{H} 5)$

Variabel demografi (pendapatan) $\left(X_{5}\right)$ memiliki nilai $t_{\text {hitung }}$ sebesar 1.268 lebih kecil dari $t_{\text {tabel }} 1.65275$, serta memiliki nilai signifikan sebesar 0.206 dimana nilai tersebut lebih dari $0,05(>0,05)$ dan bertanda positif (+), ini menunjukan bahwa variabel demografi (pendapatan) tidak berpengaruh terhadap perilaku konsumtif. Dengan demikian hipotesis kelima (H5) ditolak karena variabel demografi (pendapatan) tidak berpengaruh terhadap perilaku konsumtif

\section{Koefisien Determinasi}

Koefisien determinasi mencerminkan seberapa besar variabel independen mempengaruhi variabel dependen. Koefisien determinasi $\left(R^{2}\right)$ mengukur seberapa jauh kemampuan model dalam menjelaskan variasi variabel dependen (perilaku konsumtif). Berikut adalah tabel hasil koefisien determinasi $\left(R^{2}\right)$ :

Tabel 7

Koefisien determinasi

\begin{tabular}{|c|c|c|c|c|}
\hline Model & $R$ & R Square & $\begin{array}{c}\text { Adjusted R } \\
\text { Square }\end{array}$ & $\begin{array}{c}\text { Std. Error of } \\
\text { the Estimate }\end{array}$ \\
\hline 1 &, $693^{\mathrm{a}}$ &, 481 &, 467 & 4,714 \\
\hline
\end{tabular}

Sumber: SPSS versi 22

Berdasarkan tabel hasil koefisien determinasi $\left(R^{2}\right)$ dibawah ini menunjukan hasil bahwa nilai Adjusted $R$ Square adalah sebesar 0.467 menandakan bahwa variabel independen hanya $46,7 \%$ mempengaruhi variabel dependen, dan sisanya yaitu sebesar $53,3 \%$ pengaruh berasal dari faktor lain.

\section{HASIL DAN PEMBAHASAN}

\section{Pembahasan}

\section{Pengaruh Financial Literacy Terhadap Perilaku Konsumtif}

Berdasarkan hasil uji statistik regresi yang telah dilakukan menunjukan variabel financial literacy $\left(\mathrm{X}_{1}\right)$ dimana nilai t hitung sebesar 2,495 lebih besar dari $t$ tabel 1.65275, serta memiliki nilai signifikasi sebesar 0.013 , nilai tersebut lebih kecil dari 0.05 (sig.<0.05) dan koefisien regresi memiliki tanda positif (+),artinya financial literacy berpengaruh positif dan signifikan terhadap perilaku konsumtif. Semakin 
tinggi financial literacy yang dimiliki oleh generasi milenial dikota Subang maka akan semakin tinggi perilaku konsumtifnya. Oleh karena itu hipotesis yang diajukan peneliti ditolak. Karena hasil penelitian tidak sesuai dengan arah hipotesis walaupun berada dibawah tingkat signifikan, maka hipotesis ditolak.

Pada penelitian ini Generasi Milenial dikota subang yang berusia 20 sampai 35 tahun sudah mengetahui tentang pengetahuan keuangan,namun walapun telah memiliki pengetahuan literasi keuangan yang cukup baik, dan generasi milenial mengetahui cara mengelola keuangan dengan baik jika financial literacy nya tidak diimplementasikan dalam kehidupan pribadinya, maka generasi milenial akan berperilaku konsumtif karena memang pada dasarnya seseorang tersebut memang suka berbelanja barang - barang yang bermerek yang sering kali di iming-iming oleh diskon, atau seseorang tersebut memang pada dasarnya mempunyai gaya hidup yang tinggi sehingga financial literacy nya tidak di implementasikan di dalam kehidupannya sehari-hari, namun hanya sekedar tahu dan dipahami saja, maka dari itu jika literasi keuanganya tidak ditimplementasikan di dalam kehidupan sehari-hari maka generasi milenial akan berperilaku konsumtif. Sehingga penelitian ini menjelaskan literasi keuangan berpengaruh positif terhadap perilaku konsumtif.

Hasil penelitian ini berlawanan dengan penelitian yang dilakukan oleh Zahra Qurotaa'yun \& Asrie Krisnawati (2019) Hasil penelitian ini menunjukan bahwa literasi keuangan berpengaruh signifikan negatif terhadap perilaku konsumtif generasi milenial di kota bandung. Dengan tingkat literasi keuangan dan perilaku konsumtif yang termasuk dalam kategori sedang yang menyatakan bahwa apabila literasi keuangan semakin meningkat maka perilaku konsumtif akan semakin menurun, dan begitu pula sebaliknya. Namun penelitian ini sejalan dengan penelitian Huri liana (2019), yang menyatakan bahwa variabel financial literacy berpengaruh positif dan signifikan terhadap perilaku konsumtif, yang menyatakan bahwa literasi keuangan adalah proses atau aktifitas tentang pemahaman dan pengetahuan serta skil tentang bagimana manajemen keuangan pribadi yang tidak hanya dipahami namun tidak diterapkan dalam kehidupannya.

\section{Pengaruh Life Style Terhadap Perilaku Konsumtif}

Berdasarkan hasil uji statistik yang telah dilakukan menunjukan adanya pengaruh variabel life style terhadap perilaku konsumtif. Hal tersebut dapat dilihat dari hasil statistik uji regresi berganda yang ditunjukan dengan Variabel Life Style $\left(\mathrm{X}_{2}\right)$ dimana nilai t hitung sebesar 2,580 lebih besar dari $t$ tabel 1.65275 , serta memiliki nilai signifikasi sebesar 0.011 , nilai tersebut lebih kecil dari 0.05 (sig.<0.05) dan koefisien regresi memiliki tanda positif $(+)$, maka hipotesis kedua $(\mathrm{H} 2)$ dalam penelitian ini diterima yang menyatakan bahwa life style berpengaruh positif dan signifikan terhadap perilaku konsumtif. Hasil penelitian ini menjelaskan bahwa life style berpengaruh positif terhadap perilaku konsumtif generasi milenial dikota subang, artinya semkain tinggi life style maka akan semakin tinggi tingkat perilaku konsumtifnya

Hasil penelitian ini menjelaskan bahwa generasi milenial di kota Subang yang ber usia 20-35 tahun, dilihat dari jawaban responden bahwa gaya hidup memang harus dipenuhi karena generasi milenial di kota Subang mengikuti perkembangan jaman dan teknologi untuk membeli barang atau fashion keluaran terbaru, karena generasi milenial di kota Subang mengikuti perkembangan teknologi dalam gaya hidupnya sehingga mereka up to date terhadap barang yang sedang populer. Oleh sebab itu maka mereka lebih memilih barang yang up to date, kemasannya menarik dan bermerek dengan cara membeli barang tersebut lewat ecomerce atau online, karena dengan mereka menggunakan barang yang bermerek maka generasi milenial akan tampil lebih percaya diri dan status sosial mereka akan di anggap tinggi di depan publik atau rekan kerjanya, maka 
dari itu semakin mewah gaya hidup generasi milenial di kota Subang maka akan semakin tinggi pula perilaku konsumtinya.

Hasil penelitian ini sejalan dengan penelitian yang dilakukan oleh Delyana Rahmawany pulungan dan hastina febriaty (2018), Risa Astiningrum (2018), Danang Krisdiantoro, Dr H.susanto M.S Tri Maryati S.E.,M.M (2016),menujukan bahwa gaya hidup berpengaruh positif dan signifikan terhadap perilaku konsumtif $\mathrm{Hal}$ ini dapat disimpulkan bahwa semakin mewah hedonisme gaya hidup maka akan meningkatkan perilaku konsumtif mereka.

\section{Pengaruh Locus Of Control Terhadap Perilaku Konsumtif}

Berdasarkan hasil uji statistik yang telah dilakukan menunjukan adanya pengaruh variabel Locus Of control terhadap perilaku konsumtif. Hal tersebut dapat dilihat dari hasil statistik uji regresi berganda yang ditunjukan dengan Variabel Locus Of Control $\left(\mathrm{X}_{3}\right)$ dimana nilai t hitung sebesar $-10,480$ lebih besar dari $t$ tabel 1.65275 , dengan serta memiliki nilai signifikasi sebesar 0.000 , nilai tersebut lebih kecil dari 0.05 (sig.<0.05) dan koefisien regresi memiliki tanda negatif (-), maka hipotesis ketiga $(\mathrm{H} 3)$ dalam penelitian ini diterima yang menyatakan bahwa locus of control berpengaruh negatif dan signifikan terhadap perilaku konsumtif. Hasil penelitian ini menjelaskan bahwa locus of control berpengaruh negatif terhadap perilaku konsumtif generasi milenial dikota Subang, artinya semakin tinggi locus of control yang dimiliki generasi milenial dikota Subang maka akan semakin menurun tingkat perilaku konsumtifnya.

Hasil Penelitian ini menjelaskan bahwa locus of control berpengaruh negatif terhadap perilaku konsumtif generasi milenial di kota Subang, yang menunjukan bahwa locus of control generasi milenial dikota Subang meningkat maka perilaku konsumtif nya menurun, ini dikarenakan generasi milenial dikota Subang yang ber usia 20 35 mempunyai Locus Of control yang baik terhadap konsumsinya baik barang maupun jasa, sehingga mereka bisa mengendalikan keinginannya untuk membeli barang barang yang bermerek, mahal, meskipun di iming imingi oleh diskon mereka tetap bisa mengendalikan keinginanya sehingga mereka lebih memprioritaskan kebutuhan dari pada keinginan, oleh karena itu tidak akan mempengaruhi perilaku konsumtifnya. Sehingga penelitian ini menjelaskan bahwa locus of control berpengaruh negatif terhadap perilaku konsumtif.

Penelitian ini sejalan dengan penelitian Nailatuh Hidayah,Prasetya Ari Bowo (2018) yang menyatakan bahwa locus of control berpengaruh negatif dan signifikan terhadap perilaku konsumtif, hal ini berarti apabila locus of control meningkat maka perilaku konsumtif akan menurun, sebaliknya jika locus of control menurun maka perilaku konsumtif akan meningkat.

\section{Pengaruh Demografi (jenis kelamin) Terhadap Perilaku Konsumtif}

Berdasarkan hasil uji statistik yang telah dilakukan menunjukan tidak adanya pengaruh variabel demografi (jenis kelamin) terhadap perilaku konsumtif. Hal tersebut dapat dilihat dari hasil statistik uji regresi berganda yang ditunjukan dengan variabel demografi (jenis kelamin) $\left(\mathrm{X}_{4}\right)$ dimana nilai $t$ hitung sebesar 0.069 lebih kecil dari $t$ tabel 1.65275 , serta memiliki nilai signifikasi sebesar 0.945 nilai tersebut lebih besar dari 0.05 (sig.>0.05) dan koefisien regresi memiliki tanda positif $(+)$, maka hipotesis keempat $(\mathrm{H} 4)$ dalam penelitian ini ditolak yang menyatakan bahwa demografi (jenis kelamin) tidak berpengaruh terhadap perilaku konsumtif. Hasil penelitian ini menunjukan bahwa demografi jenis kelamin) tidak berpengaruh terhadap perilaku konsumtif generasi milenial di kota Subang, yang artinya jenis kelamin baik laki-laki maupun perempuan tidak mendorong perilaku konsumtif, karena laki-laki dan perempuan tidak memiliki perbedaan dalam berperilaku konsumtif, Setiap orang mempunyai keinginan,Seorang laki-laki ataupun perempuan akan membeli suatu barang atau jasa tidak hanya didasarkan pada kebutuhan melainkan juga 
keinginan. sehingga jenis kelamin tidak berpengaruh terhadap perilaku konsumtif generasi mlenial dikota subang.

Penelitian ini menunjukan bahwa variabel demografi (jenis kelamin) tidak berpengaruh terhadap perilaku konsumtif generasi milenial dikota Subang, hal ini dikarenakan generasi milenial di kota Subang yang ber usia 20-35 tahun menunjukan bahwa jenis kelamin tidak mendorong perilaku konsumtif, karena pada dasarnya laki-laki dan perempuan tidak memiliki perbedaan dalam berperilaku konsumtif, karena setiap orang memiliki keinginan baik laki-laki maupun perempuan, namun biasanya perempuan memang suka belanja tetapi perempuan biasanya selalu mempertimbangkan harga terlebih dahulu sebelum membeli suatu barang yang di inginkan, sedangkan lakilaki lebih jarang berbelanja namun laki-laki biasanya mudah terpengaruh dalam perilaku membeli karena tidak sabar dalam memilih, .sedangkan menurut Loix et al (2005) dan Septiani dan Rita (2013) bahwa laki-laki dan perempuan tidak memiliki perbedaan yang signifikan.

Penelitian ini bertolak belakang dengan penelitian Bashar, Ahmad and Wasiq (2013) dalam penelitiannya menjelaskan jenis kelamin berpengaruh positif terhadap perilaku konsumtif. Perempuan memiliki perilaku konsumtif yang lebih tinggi dibandingkan dengan laki-laki, dimana ketika melakukan pembelian perempuan lebih sering didasarkan pada keinginan dan kehidupan sosial,sedangkan laki-laki didasarkan pada kebutuhan. Namun Penelitian ini sejalan dengan penelitian yang dilakukan Felicia Claresta Harli (2015) yang menyatakan bahwa jenis kelamin tidak berpengaruh signifikan terhadap perilaku konsumtif, artinya antara laki-laki dan perempuan tidak memiliki perbedaan dalam berperilaku konsumtif.

\section{Pengaruh demografi (pendapatan) terhadap perilaku konsumtif}

Berdasarkan hasil uji statistik yang telah dilakukan menunjukan tidak adanya pengaruh variabel demografi (pendapatan) terhadap perilaku konsumtif.
Hal tersebut dapat dilihat dari hasil statistik uji regresi berganda yang ditunjukan dengan $\left(X_{5}\right)$ dimana nilai nilai $t$ hitung sebesar 1.268 lebih kecil dari $t$ tabel 1.65275, serta memiliki nilai signifikasi sebesar 0.206 nilai tersebut lebih besar dari 0.05 (sig.>0.05) dan koefisien regresi memiliki tanda positif $(+)$, maka hipotesis kelima (H5) dalam penelitian ini ditolak yang menyatakan bahwa demografi (pendapatan) tidak berpengaruh terhadap perilaku konsumtif. Hasil penelitian ini menjelaskan bahwa demografi (pendapatan) tidak berpengaruh terhadap perilaku konsumtif generasi milenial dikota Subang, Artinya besar kecilnya pendapatan yang diperoleh oleh generasi milenial dikota Subang maka tidak akan menurunkan perilaku konsumtifnya.

Hasil penelitian ini menunjukan bahwa variabel demografi (pendapatan) tidak berpengaruh terhadap perilaku konsumtif. Hal ini menunjukan bahwa besar kecilnya pendapatan yang dimiliki seseorang maka tidak akan mempengaruhi penurunan tingkat konsumtif generasi milenial di kota Subang yang ber usia 20 - 35 tahun, jika seseorang mempunyai pendapatan yang besar maupun kecil artinya tingkat pendapatan generasi milenial tidak akan mempengaruhi penurunan tingkat konsumtifnya, hal ini dikarenakan jika generasi milenial dikota Subang mempunyai pendapatan yang besar atau pun kecil maka mereka akan membelanjakan uangnya, dikarenakan setiap orang mempunyai keinginan, dan keinginan ataupun kebutuhan memang harus dipenuhi, namun disebabkan karna hal lain misalnya disebabkan oleh gaya hidup yang tinggi, sehingga penelitian ini menjelaskan pendapatan tidak berpengaruh terhadap perilaku konsumtif generasi milenial di kota Subang.

Penelitian ini bertolak belakang dengan penelitian yang dilakukan Felicia Claresta Harli (2015) yang menyatakan pendapatan berpengaruh positif signifikan 
terhadap perilaku konsumtif. Artinya, semakin tinggi pendapatan maka perilaku konsumtif juga akan semakin tinggi. Namun Penelitian ini sejalan dengan penelitian terdahulu Dyah Rini Prihastuty, Sri Rahayuningsih (2019) yang menyatakan bahwa pendapatan tidak berpegaruh terhadap perilaku konsumtif.

\section{Pengaruh Financial Literacy, Life Style, Locus Of Control Dan Demografi Terhadap Perilaku Konsumtif}

Berdasarkan hasil uji statistik yang telah dilakukan menunjukan bahwa adanya pengaruh dari variabel financial literacy, life style, locus of control, demografi (jenis kelamin), dan demografi (pendapatan) terhadap perilaku konsumtif. Hal tersebut dapat dilhat dari hasil uji statistik regresi yang menujukan bahwa nilai sig. $F$ adalah 0.000 dimana nilai tersebut kurang dari $0.05 \quad(\mathrm{sig}<0.05)$ yang berarti kelima variabel tersebut secara simultan berpengaruh terhadap variabel dependen. Namun berdasarkan nilai Adjusted $R$ Square $\left(R^{2}\right)$ sebesar 0.467 yang menandakan bahwa pengaruh kelima variabel independen terhadap variabel dependen hanya sebesar $46,7 \%$ bisa jadi berasal dari faktor lain yang tidak diteliti pada penelitian ini.

\section{KESIMPULAN}

Berdasarkan hasil penelitian, maka dapat ditarik kesimpulan sebagai berikut :

1. Financial literacy berpengaruh positif dan signifikan terhadap perilaku konsumtif generasi milenial dikota subang yang berusia 20-35 tahun. yang menunjukan bahwa tingkat financial literacy yang dimiliki generasi milenial di kota Subang semakin tinggi akan membuat perilaku konsumtif pun tinggi.

2. Life style berpengaruh positif dan signifikan terhadap perilaku konsumtif generasi milenial di kota subang. Yang menunjukan semakin tinggi life style generasi milenial di kota subang yang berusia 20-35 tahun maka akan semakin tinggi perilaku konsumtif.

3. Locus of control berpengaruh negatif dan signifikan terhadap perilaku generasi milenial dikota subang yang berusia 20-35 tahun, yang menunjukan bahwa semakin tinggi locus of control yang dimiliki generasi milenial di kota Subang yang berusia 20-35 tahun maka akan semakin menurun tingkat perilaku konsumtifnya.

4. Jenis kelamin tidak berpengaruh terhadap perilaku konsumtif generasi milenial di kota subang yang berusia 20-35 tahun. karena jenis kelamin baik laki-laki ataupun perempuan tidak memiliki perbedaan, karena perempuan biasanya berbelanja selalu mempertimbangkan harga, sedangkan laki-laki biasanya selalu tidak suka belanja melainkan lebih terpengaruh dalam perilaku membeli.

5. Pendapatan tidak berpengaruh terhadap perilaku konsumtif generasi milenial di kota Subang. Yang menunjukan besar kecilnya pendapatan yang di miliki oleh generasi milenial dikota Subang yang berusia 20-35 tahun tidak akan berpengaruh terhadap penurunan tigkat perilaku konsumtif.

6. Hasil penelitian ini menunjukan bahwa variabel financial literacy, life style,locus of control dan demografi (jenis kelamin), demografi (pendapatan) secara bersama-sama (simultan) berpengaruh terhadap perilaku konsumtif generasi milenial dikota Subang.

\section{SARAN DAN KETERBATASAN}

\section{Saran}

1. Saran bagi peneliti selanjutnya

a. Penelitian ini hanya menggunakan lima variabel bebas yaitu financial literacy, life style, locus of control dan demografi (jenis kelamin), demografi (pendapatan), untuk peneliti selanjutnya diharapkan menambah variabel bebas dengan menambah variabel penggunaan e-money. 
b. Penelitian ini hanya mengambil objek penelitian generasi milenial dikota subang, tetapi dapat dilakukan dikota kota lain atau bisa dilakukan dengan objek penelitian generasi milenial sejawabarat.

c. Penelitian ini hanya menggunakan kuesioner, bagi peneliti selanjutnya bisa menambahkan dengan metode wawancara.

2. Saran bagi generasi milenial di kota subang

a. Seharusnya generasi milenial dapat menerapkan pengetahuan tentang literasi keuangan sehingga dapat mengontrol perilaku belanja dengan cara mengedepankan kebutuhan dari pada keinginan. cara menerapkan pengetahuan keuangannya atau literasi keuangannya di dalam kehidupan pribadinya, misalnya seperti merancang daftar belanja agar dapat membeli barang yang lebih dibutuhkan agar pengelola keuangan bisa terkendali, sehingga meskipun pada saat itu ada barang yang sedang diskon atau promo bisa mengendalikan keinginanya.

b. generasi milenial diharapkan lebih banyak menabung dibandingkan belanja, menabung atau menyimpan uang bisa dengan berbagai cara seperti menabung uang di bank, atau dengan cara berinvestasi.

3. Saran bagi pemerintah dan lembaga keuangan

Melakukan seminar- seminar atau event maupun pelatihan di kota subang mengenai tentang literasi keuangan yang bisa mengontrol dan mengelola keuangan sehari-hari,menyiapkan dan merancang keuangan jangka panjang untuk kehidupan yang sejahtera dimasa yang akan datang, atau berbagai produk keuangan seperti cara berinvestasi dll. Event atau seminar tersebut bisa dilakukan dengan bekerja sama antara OJK dengan sekolah-sekolah, perguruan tinggi maupun intansi di subang untuk meningkatkan literasi keuangan dan menerapkan dikehidupan pribadinya.

\section{Keterbatasan}

Berdasarkan hasil penelitian yang telah dilakukan maka peneliti memberikan saran sebagai berikut :

1. Penelitian ini hanya menggunakan instrumen kuesioner sehingga belum menggambarkan secara utuh kondisi yang terjadi pada objek penelitian. Penelitian ini dilakukan pada saat terjadi nya pandemi di indonesia, terkait adanya virus covid-19 sehingga peneliti tidak terjun kelapangan langsung.

2. Penelitian ini merasa kesulitan mencari responden karena hanya menggunakan dan memanfaatkan fasilitas social media dan smarthpone.

3. Penelitian ini hanya mengambil sampel generasi milenial yang berada di kota Subang saja, sehingga penelitian ini hanya berlaku untuk dikota Subang.

\section{DAFTAR PUSTAKA}

\section{Buku}

Sugihartono, dkk. 2007. Psikologi Pendidikan. Yogyakarta: UNY Press.

Sugiyono. 2014. Metode Penelitian Kuantitatif, Kualitatif, dan Kombinasi (Mixed Methods). Bandung : Alfabeta

Sugiyono (2015). Metode penelitian kombinasi (mix methods) bandung:Alfabeta

Sugiyono. (2017). Metode Penelitian Kuantitatif Kualitatif dan $R \& D$. Bandung: Alfabeta

Ghozali, I. (2016). Aplikasi Analisis Multivariete dengan Program IBM SPSS 23.Semarang: Badan Penerbit Universitas Diponegoro. 


\section{Artikel dan jurnal}

Astuti, R. P. (2016). Pengaruh Status Sosial Ekonomi Orang Tua, Literasi Keuangan dan Life Style terhadap Perilaku Konsumsi Mahasiswa Jurusan Pendidikan Ekonomi IKIP PGRI Bojonegoro. Jurnal Edutama, 3, 50.

Anisa N. F. \& Nurdin (2019). Pengaruh literasi keuangan terhadap perilaku konsumtif. ISSN: 2460-6545

Achadiyah, B. N., \& Laily, N. (2013). Pengaruh Locus Of Control Terhadap Hasil Belajar Mahasiswa Akuntansi. Jurnal Pendidikan Akuntansi Indonesia, Vol.XI No., 11-18. Malang: Universitas Negeri Malang.

Bashar, Abu, Ahmad, irshad and Washiq,muhamad (2013). A study factors young. The journal of consummer Affairs. Vol 44 No. 2

Chita, M. C., David, L., \& Pali, C. (2015). Hubungan Self-Control dengan Perilaku Konsumtif Online Shopping Produk Fashion pada Mahasiswa Fakultas Kedokteran Universitas Sam Ratulangi Angkatan 2011. JurnaleBiomedik, 3(1), 297-302.

Danang K, Dr H.susanto M.S, Tri Maryati S.E.,M.M (2016) pengaruh iklan online, konformitas dan gaya hidup terhadap perilaku konsumtif. 13 Oktober $2016 \quad$,Magister Manajemen Universitas Muhammadiyah Yogyakarta.

Dikria, O., \& W, S. U.\& Sri Umi Mintarti. (2016). Pengaruh Literasi Keuangan dan Pengendalian Diri terhadap Perilaku Konsumtif Mahasiswa Jurusan Ekonomi Pembangunan Fakultas Ekonomi Universitas Negeri Malang Angkatan 2013. Jurnal Pendidikan Ekonomi, 9(2).
Dyah R. P, Sri R. (2018). Pengaruh Financial Literacy, Financial Behavior, Financial Attitude, Dan Demografi Terhadap Perilaku Konsumtif. Jurnal Hasil Penelitian LPPM Untag Surabaya September 2018, Vol. 03, No. 02, hal $121-134$.

Ermawati, N. (2017). Pengaruh Need for Achivment Dan Locus of Control terhadap Intensi Berwirausaha melalui Sikap Siswa Kelas Xii SMK Negeri Kota Semarang. Jurnal of Economic Education, Vol 6 No.1, Semarang: Universitas Negeri Semarang

Fattah, F. A., Indriayu, M., \& Sunarto. (2018). Pengaruh Literasi Keuangan dan Pengendalian Diri terhadap Perilaku Konsumtif Siswa SMA Muhammadiyah 1 Karanganyar. Jurnal pendidikan Bisnis dan Ekonomi,4(1), 12

Harli, Felicia Claresta dkk. (2015). "Pengaruh Financial Literacy dan Faktor Sosiodemografi terhadap Perilaku Konsumtif". Jurnal. Vinesta Vol 3 No 1, halaman 5862.

Huri, Liana (2017). pengaruh literasi keuangan dan faktor demografi terhadap perilaku konsumtif. skripsi Institut Informatika Dan Bisnis Darmajaya Bandar Lampung

Imawati, I., Susilaningsih, \& Ivada, E. (2013). Pengaruh Financial Literacy terhadap Perilaku Konsumtif Remaja pada Program IPS SMA Negeri 1 Surakarta Tahun Ajaran 2012/2013. Jurnal Pendidikan Ekonomi Universitas Sebelas Maret, 2(1), 48-58.

Machrus, Hawa'im dan Urip Purwono. (2010). Pengukuran Perilaku Berdasarkan Theory of Planned Behavior. INSAN Media Psikologi. Volume 12(1); hlm. 64-72 
Madani hatta, baihaqi, Resti

ramahdaniati,(2017). Perilaku bebagi pengetahuan akuntansi pada dosen akuntansi kota bengkulu: pendekatan theory of planned behaviour (TPB). Jurnal akuntansi, ekonomi dan manajemen bisnis)

Margaretha, Farah dan Reza Arif P. 2015.Tingkat Literasi Keuangan Pada Mahasiswa S-1 Fakultas Ekonomi.Jurnal Manajemen dan Kewirausahaan: Vol.17,No. 1,Maret 2015, 76-85

Kusumaningtyas. I (2017) Pengaruh Literasi Keuangan Dan Gaya Hidup Terhadap Perilaku Konsumtif Siswa Kelas Xi Ips Di Sma Negeri 1 Taman Sidoarjo Pendidikan Ekonomi, Fakultas Ekonomi, Universitas Negeri Surabaya

Krishna, A., Rofaida, R., \& Sari, M. (2010). Analisis Tingkat Literasi Keuangan di Kalangan Mahasiswa dan Faktor-Faktor yang Mempengaruhinya (Survey Pada Mahasiswa Universitas Pendidikan Indonesia. Proceedingsof The 4th International Conference on teacher Education (pp. 8-10). Indonesia: Join Conference UPI \& UPSI Bandung.

Krisdiantoro, D., Susanto, \& Maryati, T. (2016). Pengaruh Iklan Online,Konformitas, dan Gaya Hidup Terhadap Perilaku Konsumtif. JournalManagement.

Nurlatifah. (2018). Analisis Faktor-faktor yang Mempengaruhi Perilaku Siswa Dalam Menabung (Studi Kasus Siswa SMA Negeri Di Kota Lubuk Pakam). [Skripsi].Medan (ID): Fakultas Ekonomi dan Bisnis UniversitasSumatera Utara.

Nailatul Hidayah \& Prasetyo Ari Bowo (2018). Pengaruh uang saku. Locus of control dan lingkungan teman sebaya terhadap perilaku konsumtif.

Natasha Shanty Herawati(2015).

Pengaruh literasi keuangan dan

faktor demografi terhadap

perilaku konsumtif. Artikel IImiah

Kolaborasi Riset Dosen

\&Mahasiswa.

Nungky Irma Triyanti1 \&Usman Effendi2

(2017)Consumer Behavior: Confidence Relationships And

Conformity With Consumtive

Behavior Online Shopping Fashion

Products Users Instagram

Applications. Vol. 6 I No. 1, Hal.

51-56

Oktafikasari, Eva. 2017. Konformitas Hedonis dan Literasi Ekonomi Terhadap Perilaku Konsumtif Melalui Gaya Hidup Konsumtif. Economic EducationAnalysis Journal Vol. 6, No. 3 hlm. 685

Palamba, F. G. (2018). Pengaruh Literasi Keuangan terhadap Perilaku Konsumtif Mahasiswa Program Studi Akuntanasi Universitas Sanata Dharma.

[Skripsi]. Yogyakarta (ID): Fakultas Ekonomi Universitas Sanata Dharma.

Purwandi l. dkk, 2017,"Milenial Nusantara", PTGramedia Pustaka utama

Pulungan, D. R., \& Febriaty, H. (2018). Pengaruh gaya hidup dan literasi keuangan terhadap perilaku konsumtif mahasiswa. Jurnal riset sains manajemen, 2 (3), 103-110.

Purwandi I. dkk, 2017,"Milenial Nusantara", PTGramedia Pustaka utama

Ramdhani. N. (2009) Model perilaku penggunaan TIK "NR2007" pengembangan dari technologi acceptance model (TAM). 
Ramdhani, Neila (2011).Penyusunan Alat Pengukur Berbasis Theory of Planned Behavior.Buletin Psikologi Fakultas Psikologi Universitas Gadjah Mada Volume 19, No. 2, 2011: $55-69$.

Ramdhani, Rianti Hikmah (2019). Pengaruh literasi keuangan, electronic money, gaya hidup dan kontrol diri terhadap perilaku konsumtif.from Repositori Institusi USU, Univsersitas Sumatera Utara

Sathish, S., \& Rajamohan, A. (2012). Consumer Behavior and Lifestyle Marketing.International Journal of Marketing, Financial Services \&ManagementResearch, 1(10).

Sezin, Baysal. Dkk, 2014, "Working With Generations $X$ And $Y$ In Generation ZPeriod: Management Of Different Generations In Business Life",Mediterranean Journal of Social Sciences MCSER Publishing,Rome-Italy

Siti fatimah (2019). Pengaruh financial literacy, financial self efficacy,social economic status dan locus of control terhadap perilaku manajemen keuangan mahasiswa. Skripsi UIN SUKA Riau.

Utami, Fika Ariani Dan Sumaryono. 2008. Pembelian Impulsif Ditinjau Dari Kontrol Diri Dan Jenis Kelamin Pada Remaja. Jurnal Psikologi Proyeksi, 3(1), pp: 46-57.

zahra Qurotaa'yun, astrie Krisnawati (2019) pengaruh literasi keuangan terhadap perilaku konsumtif generasi milenial di kota bandung.Journal Accounting and Finance Edisi Vol. 3 No. 1 Maret 2019

Zahra Qurotaa'yun Astrie Krisnawati2 (2019,). Generasi Milenial Masih
Pembelanja Online Terbesar di Indonesia. Retrieved from. https://marketeers.com/generasimilenial masih-pembelanja-onlineterbesar-di-indonesia/ (diakses 5 november 2019)

Zahra Qurotaa'yun Astrie Krisnawati2 (2019,). Mengapa Generasi Millennials Suka Belanja.

Retrieved from

https://republika.co.id/berita/gayahidup/trend/17/01/31/okn5b2328mengapa-generasi-millennialssuka-belanja [Diakses 5 Januari 2020)

Zahra Qurotaa'yun Astrie Krisnawati2 (2019,)https://www.nielsen.com/id/ en/press-releases/2016/indonesiakembali-berada-pada-peringkatketiga-negara-paling-optimistis-didunia/

\section{Web}

Badan Pusat Statistik. (2019, Agustus 24). Jumlah Penduduk Menurut Kelompok Umur dan Jenis Kelamin di Kota subang 2017.Retrieved from

https://subangkab.bps.go.id/public ation/2019/08/16/94f76338bddfaf2 d68e647c4/kabupaten-subangdalam-angka-2019.html [Diakses 5 November 2019]

Indonesia Millennial Report 2019 https://cdn.idntimes.com/contentdocuments/indonesia-millennialreport-2019-by-idn-times.pdf

Statistik Gender Tematik: "Profil Generasi Milenial Indonesia 2018”. Retrieved from. https://www.kemenpppa.go.id/lib/u ploads/list/9acde-buku-profilgenerasi-milenia.pdf (Diakses 5 november 2019).

Otoritas jasa keuangan (2019). https://www.ojk.go.id/id/berita-dankegiatan/siaranpers/Pages/Siaran-Pers-SurveiOJK-2019-Indeks-Literasi-DanInklusi-Keuangan-Meningkat.aspx 
https://www.cnnindonesia.com/gaya-

hidup/20180418215055-282-

291845/alasan- generasi-milenial-

lebih-konsumtif (Diakses 5

november 2019)

https://ekonomi.kompas.com/read/2015/0

8/08/110746226/OJK.Orang.Indon

esia.Makin.Konsumtif

itagar.id/artikel/gaya-

hidup/memahami-generasi-

milenial-yang-gemar-berbelanja

https://money.kompas.com/read/2019/03/

21/161700826/survei--generasi-

milenial-lebih-boros-ketimbang-

generasi-lain (Diakses 5 Januari

2020)

https://www.topreneur.id/inilah-5-kota-di-

indonesia-dengan-jumlah-pembeli-

online-terbanyak-dalam-3-tahun-

terakhir/ (Dikases 15 desember

2019)

https://www.cnbcindonesia.com/news/201 90321091350-4-62001/ct-bicara-milenialkonsumerisme-jadi-gaya-hidup 